\title{
A review on ancient process of oral hygiene
}

\author{
Neetu Singh Siyag ${ }^{1}$, Prem Prakash Vyas ${ }^{1}$, Devendra Singh Chahar ${ }^{2}$ and Harish Kumar Singhal 1,* \\ ${ }^{1}$ P.G. Department of Ayurved Pediatrics, University College of Ayurved, Dr. S. R. Rajasthan Ayurved University, Jodhpur, \\ Rajasthan, India. \\ ${ }^{2}$ Department of Maulik Siddhanta, University College of Ayurved, Dr. S. R. Rajasthan Ayurved University, Jodhpur, \\ Rajasthan, India.
}

International Journal of Biological and Pharmaceutical Sciences Archive, 2021, 01(01), 027-030

Publication history: Received on 08 January 2021; revised on 16 January 2021; accepted on 18 January 2021

\begin{abstract}
Oral hygiene plays an important role in keeping the body healthy. Oral cavity is in direct contact with the external environment, due to which it is natural to have bacterial growth in the mouth, but by adopting the measures of oral hygiene, bacterial growth can be easily prevented and keep body healthy. In Ayurvedic classical texts Kawal \& Gandoosha are described under the heading of Dincharaya, which not only keep oral cavity disease free but also healthy too. These procedures are essential for maintaining and promoting oral hygiene. By seeing these benefits, Government of India include Kawal (oil pulling) in the National Ayurveda Protocol for the management of covid-19.
\end{abstract}

Keywords: Ayurveda, Oil pulling, National Ayurveda Protocol, Covid 19, Oral hygiene, health

\section{Introduction}

Oral hygiene is an integral part of our health. If oral hygiene is taken care of, we can avoid many diseases but it is not possible by brushing the teeth only. A common person comes in contact with the external environment each day and thousands of bacteria enter the body through mouth which is not visible to anyone with naked eyes. This is why in this time of covid-19, use of mask is compulsory and gargles; oil pulling or swishing is advised. Apart from this, some people play with their health by consuming cigarettes, cold drinks, tobacco etc. Therefore, using procedures like Kawal and Gandoosha mentioned in the classical text books of Ayurveda as prevention or treatment can be minimize the adverse effects of these bad habits. In Ayurveda, Acharyas described these measures not only as preventive but also for different oral diseases too. By using these measures, oral hygiene can be regained and growth of bacteria can be prevented.

In Kawal process the medicated oil or kwatha is filled in the mouth and swish, where as in Gandoosha process the medicated oil or kwatha prepared by various herbs is filled in the mouth to the maximum bearing quantity and hold it for some time, there should be no space to shake the liquid and gargle it in the mouth [1, 2, 3]. Gandoosha is a liquid substance and if powder is to be added to it, a quantity of Kola (half karsha or half tola) should be put in the mouth [4].

\subsection{Dharana Kala [9](duration)}

Gandoosha and Kawal should be used after the age of 5 year. These can be used three, five, seven times or till balancing of doshas.

\footnotetext{
${ }^{*}$ Corresponding author: Harish Kumar Singhal

P.G. Department of Ayurved Pediatrics, University College of Ayurved, Dr. S. R. Rajasthan Ayurved University, Jodhpur, Rajasthan, India. 
Table 1 Depicting types of Gandoosha

\begin{tabular}{|l|l|l|}
\hline S. No. & Acharya & Types \\
\hline 1 & Vagbhatta [5] & Snigdha \\
& & Shaman \\
& & Shodhana \\
& & Ropana \\
\hline 2 & Sharangdhara [6] & Snaihika \\
& & Shaman \\
& & Shodhana \\
& & Ropana \\
\hline
\end{tabular}

Table 2 Depicting types of Kawal

\begin{tabular}{|l|l|l|}
\hline S. No & Acharya & Types \\
\hline 1 & Susruta[7] & $\begin{array}{l}\text { Snehi kawal } \\
\text { Prasadi kawal } \\
\end{array}$ \\
& & $\begin{array}{l}\text { Shodhan kawal } \\
\text { Ropan kawal }\end{array}$ \\
\hline 2 & Chakrapani [8] & $\begin{array}{l}\text { Snaihik kawal } \\
\text { Prasadhan kawal } \\
\end{array}$ \\
& & $\begin{array}{l}\text { Samshodhan kawal } \\
\text { Ropan kawal }\end{array}$ \\
\hline
\end{tabular}

\section{Effects of the Procedures}

\subsection{Samyak Yoga Lakshana $[10,11]$ (proper effects)}

Vyadherpachaya (palliation of diseases or illness), tushti/ santosh (freshness of oral cavity), vaishadhyam /nirmalta (cleaning of mouth), vaktralaghavam(lightness of mouth), indriyanam prasada (sense organs tend to their work)

\subsection{Heena Yoga Lakshana [12,13] (inadequate effects)}

Kaphotklesh (excessive salivation), rasaagyana (improper functioning of taste buds), aruchi (anorexia), jadata (stiffness)

\subsection{Atiyoga Lakshana [12,13] (excessive effects)}

Mukhapaka (mouthulcers), mukha shosha(dryness of mouth), trishna (thirst), klama (feeling of exhaustion)

\section{Various types of Gandoosha and Kawal according to diseases}

\begin{tabular}{|l|l|}
\hline Gandoosha / Kawal & Effects \\
\hline Lukewarm or cool tilakalkodaka [14] & Dantharsha (Odontitis), Dantchala (loose teeth), Vataj Mukhroga \\
\hline Taila or mansrasa [14] & For Healthy person \\
\hline Ghrita or cold milk [14,15] & $\begin{array}{l}\text { Burning sensation in mouth ulcer, agantuja kshata } \\
\text { (injury),burning due to visha(poison), kshara (caustics) or agni } \\
\text { (fire) }\end{array}$ \\
\hline
\end{tabular}


International Journal of Biological and Pharmaceutical Sciences Archive, 2021, 01(01), 027-030

\begin{tabular}{|l|l|}
\hline Madhu Gandoosha [14,15] & $\begin{array}{l}\text { Daha (burning sensation), trishnaprashamana (suppresses } \\
\text { excessive thirst),cleaning of mouth, mukhavrana(mouth ulcers) }\end{array}$ \\
\hline Luke warm water [14] & Vaktralaghavam (enhances lightness in mouth) \\
\hline Taila saindhav gandoosha [15] & Dantachala(loose teeth) \\
\hline Kanji Gandoosha [15] & Mukhashosha (dryness in mouth), mukhavairasya (tastelessness) \\
\hline Saindhav,trikatu,raji(rai),aadraka[15] & Kapha nashaka \\
\hline Triphala madhu gandoosha[15] & Kapha,rakta and pitta nashaka \\
\hline Repeatedly cold water Gandoosha[16] & $\begin{array}{l}\text { Decreases excess amount of phlegm (Kapha), thirst and food } \\
\text { debris. Mouth is purified by this Gandoosha. }\end{array}$ \\
\hline $\begin{array}{l}\text { Luckwam water [16] } \\
\text { Bijora neembu, kesar, saindhav, kali mirch } \\
\text { kalka dharan as Kawal [15] }\end{array}$ & $\begin{array}{l}\text { Removes jadata (stiffness), kapha-vaatjanitaruchi (anorexia) } \\
\text { inertia) and feeling of lightness in mouth }\end{array}$ \\
\hline
\end{tabular}

\subsection{Benefits of Gandoosha and Kawal $[17,18]$}

It strengthens the jaw and improves quality of voice \& muscle mass, clears the tongue so that appetite and sense of taste improves, prevents dryness of throat and prevents chapped lips. It strengthens the teeth and gums \& also prevents sensitivity of teeth. It also seen effective in diseases like spondylitis, headache, maintaining the eyesight, dryness of mouth and rhinitis and many more supra clavicular diseases.

\section{Discussion $[19,20,21]$}

Drugs first enter in the body through its administration route and disintegrate by drug metabolizing enzymes in the intestine and liver. At the end of the process metabolite of drug absorbed and distributed all over the body through blood circulation. In some administration route like sublingual, transdermal or parental, this presystemic (first-pass) metabolism can be avoided that means drugs without going to gut and liver reach directly in the blood circulation and distributed. Gandoosha and Kawal process are the procedures which follow sublingual route. So in Gandoosha and Kawal are the procedure in which medicated decoction, ghrita, oil, honey etc directly absorbed by systemic circulation. The Gandoosha and Kawal process also increases the mechanical pressure in the buccal cavity which is helpful to increase secretion of salivary glands. Saliva works as a local antibiotic which contains IgA, IgM and lysozyme. Saliva also gives protection against bacterial invasion's wound due to contain coagulation factor 8, 9 and 10. Some toxic substances, debris and bacteria mixed with that medicated or normal Gandoosha and Kawal liquid and spitted out through this process. It maintains the $\mathrm{pH}$ of oral cavity. The $\mathrm{pH}$ of buccal cavity is neutral or non-acidic. If there is some pathological condition arises then $\mathrm{pH}$ of oral cavity converts from non-acidic or neutral to acidic pH. So Gandoosha and Kawal prevents from oral diseases by maintaining the $\mathrm{pH}$ of mouth.

\section{Conclusion}

Oil pulling method can be co-related with Gandoosha and oil swishing can be associated with Kawal. These have been quite popular these days and have lots of benefits including- oral hygiene, lustrous skin, healthy eyes etc. It is also included in Dinacharya in Ayurveda for maintain the oral hygiene and prevent growth of bacteria in mouth. It also gives strength to facial muscles which can appear as anti-aging impact in beauty. It also plays an important role to prevent as well as cure oral diseases without having any side effects. It is easy and simple procedure which can also performed in daily routine at any time simply by filled mouth with normal water till secretions are not come out from nose and eyes.

\section{Compliance with ethical standards}

\section{Disclosure of conflict of interest}

All authors declare that no conflict of interest is exist. 


\section{References}

[1] Shastri Ambikadutta,Susruta Samhita,Ayurveda Tattva Sandipika Hindi Commentary, Published By Chaukhambha Sanskrit Sansthan Varanasi,Reprint 2014; Chikitsa Sthan 40/62:Page No.229

[2] Tripathi Bramhanand, Ashtanga Hrdayam,Nirmala Hindi Commentary, Chaukhambha Sanskrut Pratishthan Varanasi, Reprint ;2015; Sutrasthana -22/12:p. 258.

[3] Tripathi Bramhanand, Sharangadhar Samhita, Dipika Hindi Commentary, Chaukhamba Surbharati Prakashan Varanasi, Reprint; 2019; Uttarakhanda 10/4:P 255

[4] Tripathi Bramhanand, Sharangadhar Samhita, Dipika Hindi Commentary, Chaukhamba Surbharati Prakashan Varanasi, Reprint; 2019; Uttarakhanda 10/5:P 255

[5] Tripathi Bramhanand, Ashtanga Hrdayam,Nirmala Hindi Commentary, Chaukhambha Sanskrut Pratishthan Varanasi, Reprint ;2015; Sutrasthana -22/1-3:P. 256.

[6] Tripathi Bramhanand, Sharangadhar Samhita, Dipika Hindi Commentary, Chaukhamba Surbharati Prakashan Varanasi, Reprint; 2019; Uttarakhanda 10/1:P 255

[7] Shastri Ambikadutta,Susruta Samhita,Ayurveda Tattva Sandipika Hindi Commentary, Published By Chaukhambha Sanskrit Sansthan Varanasi,Reprint 2014; Chikitsa Sthan 40/58-60:Page No.229

[8] Tripathi Indradeva, Chakradatta,Vaidayaprabha Hindi Commentary, Chaukhambha Sanskrit Bhawan Varanasi,Reprint 2018; Netraroga Chikitsa 59/97:Page No.357

[9] Tripathi Bramhanand, Sharangadhar Samhita, Dipika Hindi Commentary, Chaukhamba Surbharati Prakashan Varanasi, Reprint; 2019; Uttarakhanda 10/6-7:P 255

[10] Tripathi Bramhanand, Sharangadhar Samhita, Dipika Hindi Commentary, Chaukhamba Surbharati Prakashan Varanasi, Reprint; 2019; Uttarakhanda 10/20:P 256

[11] Shastri Ambikadutta,Susruta Samhita,Ayurveda Tattva Sandipika Hindi Commentary, Published By Chaukhambha Sanskrit Sansthan Varanasi,Reprint 2014; Chikitsa Sthan 40/65:Page No.230

[12] Tripathi Bramhanand, Sharangadhar Samhita, Dipika Hindi Commentary, Chaukhamba Surbharati Prakashan Varanasi, Reprint; 2019; Uttarakhanda 10/19:P 256

[13] Shastri Ambikadutta,Susruta Samhita,Ayurveda Tattva Sandipika Hindi Commentary, Published By Chaukhambha Sanskrit Sansthan Varanasi, Reprint 2014;Chikitsa Sthan 40/66:Page No.230

[14] Tripathi Bramhanand, Ashtanga Hrdayam,Nirmala Hindi Commentary, Chaukhambha Sanskrut Pratishthan Varanasi, Reprint ;2015; Sutrasthana -22/5-10:P. 257-258.

[15] Tripathi Bramhanand, Sharangadhar Samhita, Dipika Hindi Commentary, Chaukhambha Surbharati Prakashan Varanasi, Reprint; 2019; Uttarakhanda 10/9-14 \& 16:P255- 256

[16] Shastri L., Yogratanakar, Vidyotini Hindi Commentary, Chaukhambha Prakashan Varanasi, Reprint 2018; Nityapravritiprakarah P. 57-58

[17] Shastrik. ,Charak Samhita, Vidyotini Hindi Commentary, Published By Chaukhambha Bharati Academy Varanasi, Reprint;2009; Sutrastahna- 5/ 78-80:P.127

[18] Tripathi Bramhanand, Ashtanga Hrdayam,Nirmala Hindi Commentary, Chaukhambha Sanskrit Pratishthan Varanasi, Reprint ;2015; Sutrasthana -22/12:P. 258.

[19] Tripathi KD,Essentials Of Medical Pharmacology, $8^{\text {th }}$ Edition,Jaypee Brothers Medical Publishers,New Delhi,Reprint 2019; Section 1- Chapter $1^{\text {st }}$ :Page No.12

[20] Tripathi KD,Essentials Of Medical Pharmacology,8 th Edition,Jaypee Brothers Medical Publishers,New Delhi,Reprint 2019; Section 1- Chapter 3 ${ }^{\text {rd:Page No.34 }}$

[21] R B Hosamani,A Review On Gandusha: An Ayurvedic Therapeutic Procedure For Oral Disorders, IAMJ (ISSN: 2320-5091) August - September, 2017; 1(6) 